\title{
6 Pragmatic and Stylistic Aspects of Proverbs
}

\subsection{Introduction and Theoretical Framework}

Proverbs possess diverse stylistic and pragmatic potential and thus fulfill many different functions within a text. The aforementioned fact can be accessed in relevant works on the topics of stylistics and pragmatics as well as in various publications from the field of phraseology and paremiology.

Traditional stylistics ${ }^{57}$ observes phraseology in general, including proverbs, particularly with regard to elocutio, or in other words, with regard to the manner of their objective-and-situation-related linguistic interpretation. In this connection, stylistics focuses predominantly on the normative linguistic approach. Traditional stylistics is a theory about "good" style, therefore it focuses on qualities of style such as correctness, clearness, appropriateness and conciseness. It also discusses the choice and effects of individual linguistic or lexical devices respectively, which act as stylistic instruments or stylistic elements to which proverbs are assigned as well. In traditional stylistics we proceed from the premise of a language system and assume that the system offers stylistically relevant lexical (and grammatical) verbalization possibilities with inherent style-forming potential. The essence of a stylistic device emanates from its standardized deviation from natural language use. Stylistic devices are linked to various effects (influencing attention, meeting aesthetic standards - ornatus as a means of adorning and ennobling the pattern of communication, diversity of expressions, exemplification etc.).

The functions of lexical stylistic devices mainly emanate from their connotations. In this regard, we speak about stylistic markedness or stylistic labeling (with regard to a specific level of style or register), and about stylistic coloring in terms of function and semantic expressivity (i.a. Sowinski, 1991; Sandig, 1986; Fleicher \& Michel \& Starke, 1993). Lexicography in particular distinguishes between the following types of register: Literary, neutral, colloquial, slang and vulgar, which are assigned as labels to lexical items based on their characteristics. Lexicography also distinguishes between the following types of semantically-expressive stylistic coloring: facetious, euphemistic, pejorative, crude etc. (Sowinski, 1991: 129). For example, the proverb Solang der Arsch in die Hosen passt, wird keine Arbeit angefasst [ww: As long as the pants fit the ass, laziness shall cause no distress] featured in the Duden 11 (2013) dictionary, is marked as crude, while the proverb Wer nie sein Brot im Bette aß, weiß nicht, wie

57 Traditional stylistics is founded in the rhetorical theory on connotative (impressive) function and convincing (persuasive) effect of language communication

(c) BY-NC-ND (C) 2014 Vida Jesenšek

This work is licensed under the Creative Commons Attribution-NonCommercial-NoDerivs 3.0 License 
Krümmel piken [ww: Whoever has never eaten their bread in bed, does not know how crumbs prick] is marked as colloquial.

The modern discipline of linguistic stylistics ${ }^{58}$ on the other hand proceeds from the premise of a different approach towards understanding the notion of style and aims at "complete stylistic analysis of a specific text" in communicative contexts, based on the proposition that "each statement can be ascribed its respective style" and that style represents both language use and text production (Sandig, 2006: 2). "Style is the HOW - it represents the significant function-and-situation-related variation of language use" (ib.: 1). Stylistics of such kind is pragmatically oriented, since style is regarded as a manner of performing an act (Sandig, 1986 \& 2006). It is founded from a text-linguistic perspective since it holistically describes style as a feature of texts, thus it does not address only the individual elements of style. It rather addresses aspects such as plot structure, cohesion, coherence, topic progression, situationality, materiality, culturality, as well as other structural features of text. Furthermore, it is acquiring a more and more distinctive interdisciplinary character by becoming amenable to argumentation theory, persuasion research, and discourse analysis (Bußmann, 2002: 652). The holistic pragmatic action-function-and-effect potential of proverbs is in the focus of observation in such contexts, but can be described only if observed in specific textual constellations.

It can thus be ascertained that the traditional, conservative concept of stylistics regards proverbs as stylistic devices, to which it assigns individual characteristic stylistic attributes outside of textual use, while modern stylistic theories understand style as a functional-pragmatic factor and focus on observing proverbs in complex textual-situational contexts of use.

Similarly to modern, pragmatically-oriented stylistics, pragmatics also proceeds from the premise that vocabulary elements of various kinds, including proverbs, possess many textual functions. Although Filatkina (2007: 134) states that pragmatics - as a scientific sub-field of linguistics -shows "a lack of interest in phraseological problems" and this "substantial void becomes apparent [...], if it is compared to the vast amount of attempts to explain grammatical and syntactical phenomena with the assistance of pragmatics" (also Kindt, 2002), the study of phraseology has taken the findings of pragmatics into consideration since the $1970 s .{ }^{59}$ For example, descriptive pragmatic approaches can be observed when determining the scope of phraseology. The most important approach in this regard is the introduction of the class of pragmatic phrasemes or routine formulae, which can only be described with pragmatic categories (greeting phrases, congratulatory phrases, and other). Proverbs

58 It became established in the field of German Linguistics particularly due to the influential works of Barbara Sandig.

59 Filaktina (2007) provides a comprehensive overview of descriptive pragmatic approaches in the field of phraseological research. 
also belong to the aforementioned class (Harnisch, 1995; Lüger, 1999), because their functionality can only be identified and described in detail in textual and discourse contexts. Coulmas (1981) includes proverbs in his deliberations on the "pragmatic foundation of idiomatics" as well. He justifies his approach by stating that proverbs have the capacity to constitute speech acts (see Nahberger, 2002).

From a historical point of view, proverbs have fulfilled various functions, "ranging from instructions within the confines of monastic education, quick-witted responses in accordance with the rules of conversation at a royal court, all the way to comments emanating from the humanist intellectual discourse regarding the experiential content of the proverb" (Eikelmann, 2002: 95; quoted from Filatkina, 2007: 151). ${ }^{60}$ Presently, we are speaking about the social function of proverbs (termed by Grzybek, 1984), since they are "regarded as socially accepted formulations of convictions, values, and norms particular to a specific culture and era” (Burger, 2010: 107). In concrete communicative situations, they can function as expressions of speech acts such as warning, persuasion, argument, confirmation, comfort, appeasement, conviction, admonition, reprimand, assessment, characterization, explanation, description, justification, or summarization (Röhrich \& Mieder, 1977). In such cases, we speak about the contextual (pragmatic) function of proverbs. The relationships between both functions is to be observed as a reciprocal relationship, because "for example, a proverb can support an argument (= contextual function) only if the speaker and the recipient understand it as a formulation of a general rule (= social function)" (Burger, 2010: 108). A few contextual examples of the usage of proverbs use shall illustrate the aforementioned. The proverbs featured in examples (1) and (2) are explicitly expressing values and norms that are part of the socio-cultural convention, while the proverb featured in example (3) is used as a means for verbalizing advice.

(1) Ich bin schon lange alleinerziehend und frage mich, ob ich vielleicht in manchen Dingen zu streng war. Erst die Arbeit und dann das Vergnügen [ee: Business before pleasure], so bin ich erzogen worden. (SprichWort, 2010)

(2) Lügen haben kurze Beine [ee: Lies have short legs] ... so haben es die meisten schon in der Kindheit gelernt. Es lohnt sich nicht zu lügen, mit Lügen schadet man sich und andern. (SprichWort, 2010)

(3) „Sie sollten nicht mit zu viel Ehrgeiz an die Sache herangehen“, riet Jung den etwa 100 Zuhörern zu Beginn. Eile mit Weile [ee: Haste makes waste] sei vielmehr das

60 Proverbs in ancient legal texts reveal specific functionality. Ancient Germanic Law, which was passed on through oral tradition, is reflected and preserved in written form through the use of proverbs - legal rules and principles are portrayed and culture-historical contexts explained. De er zu der mul kumt, der melt e. [First come, first served](Filatkina, 2007: 151; Janz, 1992). 
Motto. Bevor der Anfänger oder Wiedereinsteiger überhaupt mit dem Sport beginne, sei erst einmal ein Gesundheitscheck fällig. (SprichWort, 2010)

The pragmatic theory of action ${ }^{61}$ represents an important step within the scope of pragmatic or holistic stylistic observation of proverbs respectively (Kühn, 1987; Čermák, 1998; Lüger, 1999). Based on this premise, it is possible to consequently, systematically, methodically and methodologically observe their illocutionary ${ }^{62}$ und perlocutionary ${ }^{63}$ potential.

For all functions of proverbs can be applied that (1) they can be identified only in specific contexts; (2) a proverb can, in principle, be assigned various functions (polyfunctionality); and (3) a specifically and intentionally applied proverb can fulfill many functions at the same time (functional cluster) Thus, an important realization is implied that proverbs cannot be attributed any functions per se without being inserted in a specific context. The functions of proverbs can only be identified through a context-and-situation-based interpretative analysis.

Lüger (1999) presents a fundamental functional-pragmatic study on German proverbs. However, part from this volume, the pragmatic potential of proverbs is prevailingly treated separately in works focusing on types of texts such as works on language use in political discourse (i. a. Koller, 1977; Elspaß, 1998), in advertising (i.a. Hemmi, 1994), in literary and journalistic texts (i.a. Lüger, 1989 \&1999; Racette, 1997; Eikelmann, 1999; Nöcker \& Rüther, 2002; Preußer, 2004; Umurova, 2005; Lewandovska, 2008; Ptashnyk, 2009), or in works on verbal communication (Nahberger, 2004). Based on previous findings it can be generally assessed that proverbs can be specifically and intentionally used in a functional-stylistic manner, which can bring forward a huge spectrum of stylistic-pragmatic effects. One can observe the differences regarding the text-type-related use of proverbs, namely their polyfunctional character is more distinctive in literary texts, as well as other kinds of opinion-based, persuasive types of text (journalistic commentaries, advertising texts). This is connected with the

61 Speech acts are generally regarded as objective- or goal-oriented activities respectively. Rather than objectively given occurrences, they represent occurrences interpreted by the recipient. They are effectively "constituted only after they have been interpreted and attributed to an occurrence by the recipient.” (Lüger, 1999: 144).

62 Illocution denotes the function of an utterance or the performative character of a sentence respectively. In addition to their meaning, utterances also contain a specific illocutionary force, a property which enables them to function as advice, cautions, recommendations etc.

63 Perlocutions are understood as the consequences of a speech act that follow the completion of a speech act. Pragmatics states „dass man illokutionäre Akte vollzieht, indem man sich äußert, und perlokutionäre Akte dadurch, dass man sich äußert” [that one prerforms an illocutionary act by uttering a statement, while a perlocutionary act or effect respectively is the result of one having had uttered a statement] 
simultaneous activation of the literal and idiomatic way of reading a proverb (Burger, 2010).

To summarize: A consensus is in place that an analysis and interpretation of the stylistic-pragmatic functionality of proverbs is possible only in a context, that is on the basis of concrete texts. Since the following considerations are largely based on pragmatically oriented and text-linguistically influenced stylistics, it has to emphasized at the very beginning that both studies - the study of stylistics as well as the study of pragmatics - are difficult to separate clearly, therefore on several places there will be certain instances of overlapping ${ }^{64}$.

The following introductory lead is of methodical-methodological nature. The identification and evaluation of stylistic-pragmatic characteristics and functions of proverbs is substantially subject to interpretation. The style-related intentions of each author and the reader-specific stylistic effects can namely be deduced only by assessing individual situations and by analytically observing individual textual statements in communicative contexts based on our linguistic and stylistic competence (Sandig, 2006: 29). Consequently, the following part will feature a discussion on the functional stylistic and i.e. pragmatic potential of proverbs, more precisely what proverbs can cause and achieve, and not what proverbs actually cause and achieve, due to the fact that it is difficult to assess the effects empirically, and in the scope of the present paper even impossible.

The following chapters will present an overview of the stylistic and pragmatic aspects of proverbs from two perspectives. Based on the perspective of traditional stylistics, section 2 discusses the (supposedly) inherent stylistic features that substantiate the specific stylistic-pragmatic effect potential of proverbs. In section 3, proverbs are described from the perspective of a holistic, functional-pragmatic perception of style, whereas it is their communicative- discourse potential that will be put under discussion. Section 4 provides an outlook on the possibilities for future research. The empirical basis for the following considerations consists of mainly German proverbs, ${ }^{65}$ in this case the presentation predominantly leans on contemporary German linguistic proverb-related findings.

64 A substantiated explanation of the correlations between stylistics, pragmatics, and text linguistics is, for example, presented by Ptashnyk (2009: 176).

65 The majority of the textual examples have been accessed from the German paremiological database SprichWort (http://www.sprichwort-plattform.org/) and from the German OWID Sprichwortwörterbuch (http://www.owid.de/) dictionary of proverbs. Individual examples were also borrowed from project papers and graduation theses of German Philology students from the Faculty of Arts of the University of Maribor. 


\subsection{Stylistic of Proverbs}

As it has already been stated, the traditional stylistic considers proverbs as lexical stylistic devices, or elements of vocabulary that have a considerable stylistic potential (see Koller, 1977; Kühn, 1987 \& 1994; Sowinski, 1991; Fleicher \& Michel \& Starke, 1993; Dietz, 1999; Filatkina, 2007; Sandig, 1986 \& 2007; Wirrer, 2007; Burger, 2010). It assigns characteristic stylistic properties to proverbs, aside of their usage in the text, according to which they can also assist in constructing the style of a text. These properties are particularly visible when it comes to the usage of slightly modified proverbs that represent a deviance from the expected and conventional due to which their stylistic markedness rises. The stylistic features include properties like rhetorical figures, belonging to stylistic levels and stylistic colouring, together with the question of their degree of expressivity. The following chapters are going to shortly elaborate on certain aspects mentioned here.

\subsubsection{Proverbs and Rhetorical Devices}

If we consider the terminology of the classical rhetoric, we can state that proverbs account to the Ornatus (ornament) of the speech, as they use their properties as rhetorical figures. It means that their communicative potential is founded in the first place in their rhetorical form. (Sandig, 2007: 161). In the German and Slovenian proverbial lore we can therefore observe different phonetic-prosodic, syntactic and semantic figures, as will be shown in the examples below:

a) Phonetical-prosodical figures:

Rhyme in different variations (internal rhyme, end rhyme, alliteration)

Eile mit Weile. (German) [ee: Haste makes waste]

Borgen macht Sorgen. (German) [ee: Better buy than borrow]

Ohne Fleiß kein Preis. (German) [ee: No pain, no gain]

Mit Geduld und Spucke fängt man jede Mucke. (German) [ee: Softly, softly, catchee monkey]

Kindermund tut Wahrheit kund. (German) [ee: Children and fools tell the truth]

Brez dela ni jela. (Slovenian) [ee: No pain, no gain]

Gliha vkup štriha. (Slovenian) [ee: Birds of a feather flock together]

Probieren geht über studieren. (German) [ee: The proof of the pudding is in the eating]

Jedem Tierchen sein Pläsierchen. (German) [ee: Different strokes for different folks]

Rhytmical pattern

Was du heute kannst besorgen, das verschiebe nicht auf morgen. (German) [ee: Never put off until tomorrow what you can do today] 
Morgen, morgen, nur nicht heute, sagen alle faulen Leute. (German) [ee: Never put off until tomorrow what you can do today]

Kjer se prepirata dva, tretji dobiček ima. (German) [ee: When two people quarrel, the third one rejoices]

b) Syntactic figures:

Figures of addition (repetition, accumulation): anaphora, epiphora, anadiplosis, kyklos, tautology

- anaphora, repetition of a word at the beginning od the following part of the sentence

Andere Länder, andere Sitten. (German) [ee: When in Rome, do as the Romans do] Aus den Augen, aus dem Sinn. (German) [ee: Out of sight, out of mind]

- epiphora, repetition of a word at the end of the following part of sentence Geteiltes Leid ist halbes Leid. (German) [ee: A sorrow shared is a sorrow halved] Wer A sagt, muss auch B sagen. (German) [ee: In for a penny, in for a pound] Kdor se zadnji smeje, se najslajše smeje. (Slovenian) [ee: He laughs best that laughs last]

Kdor hitro da, dvakrat da. (Slovenian) [ee: He who gives quickly gives twice]

- anadiplosis, repetition of the last word of a sentence at the beginning of the following sentence

Wer zuletzt lacht, lacht am besten. (German) [ee: He laughs best that laughs last]

Wo Rauch ist, ist auch Feuer. (German) [ee: There's no smoke without fire]

- kyklos, repetition of a word as a frame

Nikoli ne reci nikoli. (Slovenian) [ee: Never say never]

Pomagaj si sam in bog ti bo pomagal. (Slovenian) [ee: Help yourself and God will help you]

- tautology, repeating the contents to enhance its effect

Sicher ist sicher. (German) [ww: Sure is sure]

Versprochen ist versprochen. (German) [ee: A promise is a promise]

Figures of omitting: ellipsis

- ellipsis, omitting one or more of the grammatically necessary parts of sentence [Das] Ende [ist] gut, alles [ist] gut. (German) [ee: All's well that ends well]

Konec [je] dober, vse [je] dobro. (Slovenian) [ee: All's well that ends well]

Figures of positioning/repositioning: parallelism, oxymoron

- parallelism, sequence of identical syntactic structures

Kommt Zeit, kommt Rat. (German) [ee: Time will tell]

Vertrauen ist gut, Kontrolle ist besser. (German) [ee: Trust, but verify]

Dvakrat premisli, enkrat stori. (Slovenian) [ee: Think twice before you act/speak]

- parallelisms, sequence of clauses with identical contents 
Auge um Auge, Zahn um Zahn. (German) [ee: An eye for an eye and a tooth for a tooth]

Oko za oko, zob za zob. (Slovenian) [ee: An eye for an eye and a tooth for a tooth]

- parallelism, sequence elements with contrastive content

Kdor visoko leta, nizko pade. (Slovenian) [ee: Pride comes bevor a fall]

Was sich liebt, das neckt sich. (German) [ee: Teasing is a sign of affection]

- oxymoron, linking oppositions that usually exclude each other

Weniger ist mehr. (German) [ee: Less is more]

Eile mit Weile. (German) [ee: Haste makes waste]

Manj je več. (Slovenian) [ee: Less is more]

Hiti počasi. (Slovenian) [ee: Haste makes waste]

c) Semantic figures (tropes):

Comparison

Wie man sich bettet, so liegt man. (German) [ee: As you make your bed, so you must lie on it]

Wie der Vater, so der Sohn. (German) [ee: As father, as son]

Kakor ti meni, tako jaz tebi. (Slovenian) [ee: Tit for tat]

Metaphor (with personification)

- empty bag standing for hungry people

Ein leerer Sack bleibt nicht stehen. (German) [ww: An empty bag cannot stand upright]

Prazna vreča ne stoji pokonci. (Slovenian) [ww: An empty bag cannot stand upright]

- dogs for people

Hunde, die bellen, beißen nicht. (German) [ee: Barking dogs never bite]

- still waters for people

Stille Wasser sind tief. (German) [ee: Still waters run deep]

Metonymy (with personification)

- pars pro toto, full stomach for people who are fed

Ein voller Bauch studiert nicht gern. (German) [ww: A fat belly, a lean brain]

Poln želodec nerad študira. (Slovenian) [ww: A fat belly, a lean brain]

- pars pro toto, lots of hands for lots of people

Viele Hände, schnelles Ende. (German) [ww: Many hands make light work]

Več rok več naredi. (Slovenian) [ww: Many hands make light work]

The rheotorical-stylisitc potential of such proverbs is very versatile and reaches from exemplification, explanation, specification, intensifying, accentuation, and exaggeration to pointing, poeticizing, concealment and heightening the images and expressivity (among others in Sowinski, 1991: 130; Sandig, 2007: 161). The effects that are accomplished are actually the noticeable deviation from the expected in certain 
contexts, i.e. from what is actually normal and stylistically neutral in certain communicative contexts.

\subsubsection{Proverbs and Stylistic Registers}

According to Koller (1977: 54), the stylistic potential of proverbs exists in their belonging to different stylistic registers. It is actually an aesthetic quality, namely the "distinction that goes back to the three styles of the ancient rhetoric [...], literary, normal, and colloquial” (Bußmann, 2002: 654; Sowinski, 1991: 127). The corresponding registers are thus connected with the positive (literary-elevated) and negative connotations (colloquial). The lexicography mentions here the term stylistic labeling, and we can very often read registers as vulgar-rough- colloquial- simple/neutral - below neutral, whereas in the new lexicography the starting point are the three "main registers": above neutral - neutral - below neutral (Sandig, 2006: 291). This is due to the fact that the subregisters in the negative scope of connotation (colloquial, slang) are very difficult to distinguish clearly (more information about this can be read in the Chapter 2.3 of this paper), but also because the lexicographically inherited stylistic labels are less based on theory and, practically seen, not consistent and therefore questionable (Burger, 2010: 195). The labeling of proverbs as colloquial in older lexicography was introduced by Koller (1977: 59) and was based on the widespread opinion that they occur in everyday situations; therefore the label colloquial is to be understood as an indicator of their occurrence in speech and not as a register. In written communication proverbs function as colloquial expressions with higher expressivity and clarity. Besides, labeling proverbs as colloquial is often connected with their folkloristic and figurative character.

We can conclude that Sandig (2006: 291) was right when he stated the "there are no sharp boundaries" between the stylistic registers, mostly because the variable individual experience and language or stylistic competence, as well as the versatile usage of proverbs. It is therefore appropriate to start from the fact that some expressions isolated from the text are very difficult to assign to a stylistic register. It is namely "due to the connection with elements of other language levels and also with the versatile text features" (Sandig: 291). In other words: if we attempt to obtain a comprehensible assigning to stylistic registers, it is necessary to consider the complex factors of proverb usage in context.

\subsubsection{Proverbs and Stylistic Colouring}

As it has already been mention, the stylistic potential of proverbs implies also the so called stylistic colouring with their functional and semantically-expressive nature (Sowinski, 1991: 129). 
Under functional stylistic colouring, there are the connotations understood, "which a word /here it is a proverb/ receives through its way of creation and functional usage" (Sowinski, 1999: 129). Proverbs receive their stylistic potential according to their usability/not usability in certain communicative areas/text types (diatextual label), according to their occurrence in oral and written communication (diamedial label), their appearance in formal/informal situations (diaphasic label), according to the usage restricted to a social group (diastratic label). An example of diamedial label of a proverb would be colloquial (see Koller's quote above, 1977), which, unlike the unmarked neutral, is considered to be limited in terms of usage to the spoken language. A diaphasic label is formal/informal, according to the criteria of level of formality in a communicative situation. Under diatextual marking could be a poetic/ literary/administrative understood for the preferred proverb usage in literary, poetic and administrative types of texts. A diastratic marking is e.g. familiar/child language and stands for the restrictive usage within a social group (Hrisztova-Gotthardt, 2010: 123 according to Hausmann, 1989).

Under the term semantic-expressive style colouring there is a "transposition of stylistic synonyms in the same context or /.../ expressions that exhibit additional connotations within a stylistic register or more stylistic registers" understood (Sowinski, 1991: 129), the lexicographic markings being humorous, euphemistic, pejorative, ironic etc. Here also we can consider the problem of an isolated assigning of certain markings to concrete proverbs, as discussed above. Therefore it can happen that the same proverb is marked differently or several times in dictionaries, as is shown in the case of the following proverb: Adel verpflichtet/noblesse oblige: bildungssprachlich, oft scherzhaft [the gentry indebts: formal, usually humorous] (Duden Universalwörterbuch), oft ironisch [usually ironic](Duden 11), no marking (Duden online).

\subsubsection{Proverbs and the Feature of Expressivity}

Proverbs (and similar strongly idiomatic non-sentence-like phraseological units) are understood as particularly expressive, strongly eidetic lexical means with a metaphoric foundation based on Bally's understanding of stylistics (1909), according to which particular lexical means are predestined for conveying expressive content. In contrast to non-idiomatic expressions, proverbs possess so-called semantic added value in the sense of emotional-expressive coloring (Schmale, 2010: 99 and works referenced there). The main question in this regard is if the expressive potential is inherent to proverbs and if proverbs are expressive a priori or if expressivity is just a feature, which proverbs develop during actual textual usage in a particular interaction situation only. The assumption of presupposed expressivity emanates from the briefly outlined lexicographic practice, in accordance with which individual expressions, which are isolated from text, are, for example, labeled with style markers referring to an emotional-expressive register. Drescher (1997) postulates a contextual dependency of 
the expressive feature of lexical utterances (phraseological in particular), according to which it can be realized, identified, and analyzed only in concrete contexts. The following example from a German talk show shall be used for the purpose of illustration:

\section{(4) F fragt einen jugendlichen Straftäter, ob er nachts gut schläft}

F: dann sacht ma:n- ähm (n) schlechtes Gewissen is nich $\boldsymbol{n}$ gutes Ruhekissen alsogeht di:se Geschichte mit einem in die Nacht rein, [...] also träumst du davon (cited from Schmale, 2010: 107)

A precise analysis of the sequence organization does not reveal a high degree of expressivity for the proverb Ein gutes Gewissen ist ein sanftes Ruhekissen [ee: A clear conscience is a good pillow] - which was intensely modified to express negation (the modified statement roughly translated into English establishes the fact of a guilty conscience not being a good pillow) - compared to the degree of expressivity attributed to the subsequent non-phraseological paraphrase (Schmale, 2010: 107). Thus, proverbs with figurative metaphors cannot be regarded as more expressive than nonphraseological expressions per se. The degree of expressivity clearly does not depend on structure-based metaphorical vividness alone (or primarily) (see paragraph 2.1), but it depends more on the contextual, situational factors. A possible exception is represented by proverbs, which topic are emotions and threefore yield expressivity. For example:

(5) Liebe macht blind [ee: Love is blind], heißt es, und ohne in Erklärungsnöte zu geraten, kann man behaupten: Im streng medizinischen Sinne stimmt das nicht. Will man damit aber ausdrücken, dass ein wenig der Blick für die Realität verloren geht, dann ist da etwas dran. (SprichWort-Plattform)

Since the present paper proceeds from the argument that expressivity represents a quality of proverbs that can be established only by analytically observing respective context-dependent relations, it seems appropriate to speak about "possible sequential expressivity" (Schmale, 2010: 104). An important factor for the higher degree of expressivity are the so called conversational processing or meta-discursive activities (Schmale, 2010: 101), that accompany the usage of individually selected idiomatic expressions and can be interpreted as indicators of or hints to the degree of expressivity of a text segment or an expression containing proverb:

(6) Der Spruch klingt banal, hat aber immer Gültigkeit: Zeit ist Geld [ee: Time is money]. Deshalb helfen den Eisenbahn-Gesellschaften auch die besten Image-Kampagnen nichts, wenn der Lkw trotz Staus, Mautschranken und Zollstellen seine Fracht früher beim Kunden abliefern kann. 
Proverb-specific modifiability, ${ }^{66}$ or, in other words, a deviation from what is expected as the norm in concrete communicative situations that triggers surprising effects at the same time, contributes to increases in the degree of expressivity as well. However, the various effects of modifications strongly depend on the recipient's previous knowledge. The recipient has to be able to identify the usual form - the form objectively regarded as "normal", in order to understand specific modifications - the creative, playful usage of language has to be identified. In this regard, Ptashnyk (2009: 187) refers to an "intriguing, expressive, and unexpected verbalization of thought"; for example Liebe geht durch die Steuerprüfung [roughly adapted into English as The way to a man's heart is through tax auditing]; a modification of the proverb Liebe geht durch den Magen [ee: The way to a man's heart is through his stomach], implying that whoever has an aptitude for cooking, will not struggle to gain the affection of others.

To summarize: Proverbs generally become stylistically relevant in textual contexts and having specific conventional rules of usage in the background, whereas any deviation from a norm or from the usual, anticipated usage in a communicative situation increases the stylistic potential and triggers certain effects at the listener/reader. For this reason, the stylistics of proverbs shall henceforth also be observed from the perspective of pragmatics.

\subsection{Pragmatic Aspects of Proverbs}

The term pragmatics commonly refers to the study of language use and theory of speech acts in concrete communicative situations (Linke \& Nussbaumer \& Portmann, 1996: 169). If a speech act is perceived as an intention-driven and goal-oriented act of writing or talking, then the central aspects of the so-called phraseopragmatics (Lüger, 1999), are aspects of function "what is uttered with communicative intent, fulfils a function, and has a purpose" (Lüger, 1999: 177). As indicated in the introductory part of this paper, proverbs possess many textual functions and can function as expressions of speech acts in concrete communicative situations. We will therefore observe which functions proverbs fulfill in specific communicative situations, what is their purpose, their speech-act potential, and what do they mean as expressions in communication.

66 Ptashnyk (2009) presents a comprehensive analytical illustration of phraseological modifications and their respective textual functions. 


\subsubsection{Argumentative Functions of Proverbs}

Proverbs often and effectively contribute to the linguistic forming of argumentative structures (Kindt, 2002: 278; Wirrer, 2007: 175). The argumentative potential of proverbs has been known since the classical period of rhetoric. Aristotle, for example, regarded the so-called maxims, to which he assigned proverbs as well; as the most important argumentative tools, and the argument itself as the most important tool of persuasion. Proverbs are particularly relevant in argumentative contexts because they represent generalizing statements "about factual and normative regularities (in the broad sense), which can act as argumentative warrants" (Kindt, 2002: 280). They do not explain the concrete or the particular, but rather the general and the abstract, and can therefore function as generalized advice, instructions how to act, justifications of actions, or explanations of actions. Hence, they possess particular persuasive power due to which they serve as convincing arguments in relevant contexts (Wirrer, 2007: 175$)^{67}$.

How are then proverbs utilized for the purposes of argumentation? In the following, three aspects of the argumentative potential of proverbs will be observed with reference to Wirrer (2007) and his multi-perspective explanation of phraseology (and proverbs) with regard to the notion of argumentative function.

a) The argumentative function of proverbs is based on their syntactic-logical structure.

The hypothesis is based on the widespread opinion according to which proverbs; as hinted above; are regarded as universal statements or generalizing propositions respectively, which provide arguments, i.e. justifications and explanations for acts. ${ }^{68}$ In Wirrer (2007), the potential claim of generalization is both specified and relativized. In this regard there are proverbs that contain explicit universal quantifiers ${ }^{69}$ :

Aller Anfang ist schwer [ee: All beginnings are difficult] $\rightarrow$ It applies for all beginnings that they are difficult;

Alle Wege führen nach Rom [ee: All roads lead to Rome] $\rightarrow$ It applies for all roads that they lead to Rome; it applies for all different ways and manners that they can lead to success or reaching the goal;

67 According to Searle's explanation of illocutionary acts (1983) argumentative speech acts are classified as assertives (statements, claims etc.), with which the speaker makes reference to the level of validity and reliability (primarily to the verity or falsity) of an argument and thus performing a perlocutionary act (the speaker achieves an effect that goes beyond the illocutionary act). See paragraph 3.2. 68 Burger (2010: 118): "Since proverbs are generally universal statements, they are suitable for supporting particular statements as inference rules in argumentative contexts.” Although according to Burger, this particular function is a historical function, which is not regarded as central in contemporary proverb usage.

69 A universal quantifier is considered as a basic predicate logic symbol that is verbalized in German as alle (all) or jede/r (each, every) respectively. 
Jeder ist seines Glückes Schmied [ee: Every man is the architect of his own fortune] $\rightarrow$ It applies for every person that they are the architect of their own fortune; it applies for everyone that they are able to actively and positively influence the outcome of certain situations and are therefore solely responsible for what they achieve.

The following context-based example shall illustrate the aforementioned:

(7) Jeder ist seines Glückes Schmied [ee: Every man is the architect of his own fortune]; so könnte das Credo unserer Leistungsgesellschaft lauten. Und da ist auch viel Wahres dran. Wir haben die Verantwortung, unser Leben zu gestalten. (OWID Sprichwörterbuch)

The validity of the content of the proverb implying that everyone is "able to actively and positively influence the outcome of certain situations and are therefore solely responsible for what they achieve" (see OWID Sprichwörterbuch) is valid $n$ the individual level, while also being transferred to the social level at the same time.

On the other hand, there are also proverbs without explicit quantifiers where the potentially generalizing content becomes recognizable only if the missing quantifiers are inferred ${ }^{70}$. This means that the respective recipient complements them based on active previous knowledge. This may possibly lead to different interpretation of the text and the corresponding argument. For example:

Ausnahmen bestätigen die Regel [ee: The exceptions prove the rule] $\rightarrow$ It applies for all/some/ many exceptions that they prove the rule;

Ende gut, alles gut [ee: All's well that ends well] $\rightarrow$ If the end is well, then all is well $\rightarrow$ It always/ often applies that: If the end is well, then all is well;

Wer rastet, der rostet [ee: He who rests, rusts] $\rightarrow$ It applies for all/some/many who rest that they rust.

The following example shows that inferences can also emanate from doubts in and negations of a generalized statement:

(8) Mit dem eigenständigen Tarifvertrag haben die Kontrahenten ihren wichtigsten Konfliktpunkt offensichtlich vom Tisch. [...] Ende gut, alles gut also? Wohl kaum. Mit Ruhm bekleckert haben sich beide Seiten in den vergangenen Monaten nämlich nicht gerade. (OWID Sprichwörterbuch)

70 Inference is an act or a process whereby textual information is complemented by active previous knowledge in a manner that enables the recipient to draw conclusions and derive meaning from the context. 
The possible doubt in the validity or the negation of the proverb-specific universal statement ( $\rightarrow$ It always/often applies that: If the end is well, then all is well) leads to the conclusion that the argumentative function of proverbs, which is founded in the syntactic-logical structure, is not stable or not absolutely given. It can only be carried out and understood in and interpretative and concrete contextual frame.

b) The argumentative function of proverbs is based on their occurrence in syllogistic structures.

Aristotelian rhetoric regards proverbs as elements featured in syllogisms ${ }^{71}$ : they either verbalize one of the two premises (propositions) or the conclusion.

In the following example, the proverb represents the second premise (Ausnahmen bestätigen die Regel [ee: The exceptions prove the rule]), from the generalizing interpretation of which $(\rightarrow$ Alle Ausnahmen bestätigen die Regel [All exceptions prove the rule]) a conclusion is derived ( $\rightarrow$ in Spielhallen darf man rauchen [Smoking is allowed in gambling establishments]):

(9) Grundsätzlich gilt das Rauchverbot in allen Gastronomiebetrieben und öffentlichen Räumen, aber Ausnahmen bestätigen bekanntlich die Regel: In niedersächsischen Spielhallen zum Beispiel darf geraucht werden, [...] (OWID Sprichwörterbuch)

Contrary to the previous example, in the following example the proverb functions as a conclusion (Was sich liebt, das neckt sich [ee: Teasing is a sign of affection]). Based on the generalizing interpretation $(\rightarrow$ Alle, die sich lieben, necken sich [All who love each other, quarrel]), the conclusion is regarded as an inductive conclusion derived from the first ( $\rightarrow$ Christoph wird von Stefan beschimpft [Christoph is being berated by Stefan]) and the second premise ( $\rightarrow$ Christoph ist Stefans bester Freund [Christoph is Stefan's best friend]):

(10) Und obendrein muß Christoph in Schach gehalten werden, denn der beschimpft ihn abwechselnd mit „Olte Hex!“ und „Kampfmaschine!“. Also entspinnt sich zwischen den beiden ein Dialog, der genausogut aus dem Büroalltag gegriffen sein könnte: „Olte Hex!“", „Macker!“ [...] usw. Christoph ist Stefans bester Freund und was sich liebt, das neckt sich eben. (OWID Sprichwörterbuch)

71 Syllogism are logical arguments in which one proposition (the conclusion) is inferred from two or more others (the (major or minor) premises) of a specific form. Each of the premises has one term in common with the conclusion in a major premise, this is the major term (i.e., the predicate of the conclusion); in a minor premise, it is the minor term (the subject) of the conclusion. The premises and the conclusion are statements that are either true or false 
c) The argumentative function of proverbs is based on the fact that they verbalize topoi.

Proverbs also occur as linguistic realizations of topoi within syllogistic argument structures. Topoi are understood as "argumentative resources from which the individual making an argument derives what best fits their purpose" (Ottmers 1996; quoting Wirrer, 2007: 180). Proverbs are regarded as such argumentative means because they are ideal for verbalizing one particular or several different topoi ${ }^{72}$ : the topos of time, cause, consequence, potentiality, means, similarity etc. ${ }^{73}$ There are following dominant topoi that can be deduced from the proverbs below: Kommt Zeit, kommt Rat [ee: Time will tell] $\rightarrow$ time; Übung macht den Meister [ee: Practice makes perfect] $\rightarrow$ cause; Wer A sagt, muss auch $B$ sagen [ee: In for a penny, in for a pound] $\rightarrow$ consequence; Wer wagt, gewinnt [ee: No guts, no glory] $\rightarrow$ potentiality; Mit Speck fängt man Mäuse [ee: Good bait catches fine fish] $\rightarrow$ means; Der Apfel fällt nicht weit vom Stamm [ee: The apple doesn't fall far from the tree] $\rightarrow$ similarity. Although, it can be determined only after observation of the textual usage which topos is in the foreground. Let us compare the following two contextual examples:

In the example (11) it is the topos of similarity in the foreground; but the typical usage of the proverb Der Apfel fällt nicht weit vom Stamm [The apple doesn't fall far from the tree] does not convey similarity alone. It additionally conveys genetically and otherwise determined traits one shares with their ancestors ${ }^{74}$ - consequently, the particular proverb also represents the topos of cause (Kindt, 2002: 280):

(11) Der Apfel fällt nicht weit vom Stamm: Jack Osbourne [...]befindet sich zum Drogen- und Alkoholentzug in einer Klinik. Schuld an der Sucht sei unter anderem der Rummel um seine Person[...] Sein Vater Ozzy Osbourne kämpft seit Jahrzehnten gegen seine Drogen- und Alkoholsucht. (OWID Sprichwörterbuch)

On the other hand, the topos central to the proverb Mit Speck fängt man Mäuse [ee: Good bait catches fine fish], used in example (12), is the topos of means, while the topoi of potentiality ( $\rightarrow$ die Aussicht mit den Wählern zu sprechen [the prospect of speaking with the voters]) and consequence ( $\rightarrow$ die Wähler dadurch für die aktuelle politische Idee $\mathrm{zu}$ gewinnen [to convince the voters to embrace the topical political agenda as a result]) can be identified as well. The lexis and the usage of metaphors are

72 Wirrer (2007: 181): "It can be generally assessed that [...] topoi and phrasemes express varying degrees of affinity."

73 Wirrer $(2007$; 181) provides an illustration of the topoi and the corresponding phrasemes (incl. proverbs).

74 The examples of meaning and usage illustrated in the OWID Sprichwörterbuch dictionary of proverbs: "Is said when children in the course of their lives develop the same way as their ancestors, because there are certain characteristics or ways of behaviour within a family that are being passed on to next generations or inherited." 
bound to the proverb-specific eidetic character (Raclette, auf den Geschmack bringen [raclette, to whet one's appetite]) and additionally enhance the argumentative function of the proverb:

(12) Mit Speck fängt man Mäuse. Isabella Stäheli will übers Raclette mit den Wählern ins Gespräch kommen und sie so auf den grünen Geschmack bringen. (OWID Sprichwörterbuch).

The argumentative potential of proverbs is substantiated on various levels. It is substantiated in their syntactic-logical formal structure, in their usage in syllogistic schemes, as well as in their usage as means for verbalizing argumentative topoi. It appears though, as if the convincing effect of proverbs in argumentative contexts grounds primarily on the category-specific topos of authority (Wirrer, 1999: 431; Hoffmann, 2009: 11). Proverbs are perceived as so-called universally applicable expressions of folk wisdom with a convincing effect. Until the period of enlightenment the authority of the argumentative proverbial saying was highly regarded, whereas later these were degraded as stereotypical sayings. Currently we speak about a shift in the function of proverbs and consequently about the loss of their argumentative function (Burger, 2010). As it has been shown, proverbs are still being used as argumentative means. Referring to Hoffmann (2012), proverbs reflect important structures of argumentative thinking in a speech community, which are still being used, as before. It has not yet been established what their validity and their efficiency ground on. It may be assumed that the category of authority does not play an important role anymore and that the general psychological and social principles, combined with their connectedness with the abstract patterns of everyday argumentation, are what is central here. $^{75}$

Based on the fact that proverbs are still being used both commonly and frequently in argumentative contexts, it would be of advantage to subject proverbs to additional research from the argumentation-theoretical and pragmalinguistic point of view.

\subsubsection{Proverbs as Items of Speech Acts in Non-argumentative Contexts}

As presented above, proverbs are frequently used to carry out speech acts in argumentative contexts, but they are also used similarly frequently to perform speech acts in non-argumentative contexts. Pragmatics, or speech act theory (introduced by Austin and Searle) to be more precise, distinguishes between representative (assertive), direct, commissive, expressive and declarative speech acts, and proceeds from the assumption that phrasemes (including proverbs) also contribute to the textual

75 Hoffmann (2012) presents a detailed study on the argumentative structures of German proverbs. 
realization of speech acts. Proverbs can therefore function as assessments, demands, advice, warnings, threats etc.

a) Proverbs as xpressions of representative (assertive) speech acts

Representative or assertive speech acts express the commitment of the speaker/writer to stating the truth (to declare, to ascertain, to claim, to report, to describe, to notify, to inform, to predict, to classify etc). The proverb Alles hat ein Ende [ee: All good things must come to an end], featured in example (13), represents an assertion, while the proverb Übung macht den Meister [ee: Practice makes perfect], featured in example (14), represents a prediction.

(13) „JederSommertagkönnte derletztesein.Das denkeichjetztöfter.Alleshat einEnde”, sagte er leise und schaute dabei wehmütig aus dem Fenster. (Sprichwort-Plattform)

(14) Übung macht den Meister. Und regelmäßiges Training macht Beine, Bauch und Popo topfit für den Sommer. (Sprichwort-Plattform)

b) Proverbs as expressions of directive speech acts

Directive speech acts are used as demands directed to the recipient/reader in order to convince them to take a particular action or to refrain from taking a particular action (to demand, to assign, to request, to order, to threaten, to advise, to allow, to advise, to forbid, to force; as well as other imperative verbs). The proverb Den Mutigen gehört die Welt [ee: Fortune favors the brave], featured in example (15), is used to emphasize a demand, the proverb Man kann nicht auf zwei Hochzeiten tanzen [ee: You cannot dance at two weddings], featured in example (16), is used to express a restriction, the proverb Erst denken, dann handeln [ee: Think before you act/speak], featured in example (17), can be interpreted as advice, while the proverb Übung macht den Meister [ee: Practice makes perfect], featured in example (18), expresses encouragement.

(15) Keine Ausreden mehr, kein Herumreden mehr, Handeln ist gefragt. Den Mutigen gehört die Welt, die Zauderer werden vergessen. Alle schauen auf die ÖVP und erwarten etwas - das muß man in den Parteizentralen doch erkennen. (SprichWort-Plattform)

(16) „Warum sollen wir in Europa nicht zwei Pässe haben“, fragt ein Mann, der sich als „Türke mit deutschem Paß“ zu erkennen gibt, einen älteren Herrn. „Man kann nicht auf zwei Hochzeiten tanzen“, sagt der. (SprichWort-Plattform)

(17) „Erst denken, dann handeln“, raten die Dreieicher Grünen dem Magistrat und da namentlich dem Sozialdezernenten und Ersten Stadtrat Berthold Olschewsky (CDU). Es 
geht um die geplante Erweiterung des Jugendzentrums in der Sprendlinger Benzstraße. (SprichWort-Plattform)

(18) Nun können wir gemeinsam tanzen und können mit Sicherheit behaupten, dass das Tanzen unser größtes Hobby ist. Also: Wenn es am Anfang nicht klappt - nur nicht aufgeben - Übung macht den Meister (SprichWort-Plattform)

c) Proverbs as expressions of commissive speech acts

Commissive speech acts commit a speaker to (voluntarily) do or refrain from doing something in the future. A speaker uses commissives to express intent (to promise, to assure, to threaten, to guarantee, to comply etc.) Under the proverb Aufgeschoben ist nicht aufgehoben [ww: Postponed is not abandoned], featured in example (19), a promise/as reassurance can be implied, the proverb Man beißt nicht die Hand, die einen füttert [ee: Do not bite the hand that feeds you], featured in example (20), can be understood as a warning, the proverb Wer wagt, der gewinnt [ee: No guts, no glory], featured in example (21), expresses a guarantee, while the proverb Wer schön sein will, muss leiden [ee: Beauty knows no pain], featured in example (22), can be interpreted as acceptance of an otherwise unreasonable approach:

(19) Aufgeschoben ist nicht aufgehoben, das versichert [...] Bernd Michelitsch, der Projektleiter des Hotels [...]. Zwar soll es nun doch erst 2009 eröffnet werden, an ein Aus für die Pläne ist aber nicht gedacht. (SprichWort-Plattform)

(20) Ob dies als Drohung zu verstehen sei? Haider: „So geht man nicht mit einem Partner um, der den anderen bis zur Stunde gut behandelt hat. Man beißt nicht die Hand, die einen füttert." (SprichWort-Plattform)

(21) Alles was Sie anpacken gelingt. Waage: Wer wagt, der gewinnt. Venus schenkt Ihnen viele zauberhafte Stunden mit Ihrem Herzblatt. (SprichWort-Plattform)

(22) Wer schön sein will, muss leiden. Das spürt jetzt auch Victoria Beckham. Weil sie seit Jahren nur super-hohe High-Heels trägt, sind ihre Füße total kaputt. (SprichWort-Plattform)

d) Proverbs as expressions of expressive speech acts

Finally, proverbs are also used to carry out expressive speech acts. The speaker's current state of emotion plays here a central role (to apologize, to praise, to criticize, to congratulate, to complain, to reprimand, to console). This way the proverb Irren ist menschlich [To err is human], featured in example (23), expresses an apology, the proverb Das Werk lobt den Meister [ww: The work praises the craftsman], featured in 
example (24), expresses praise, the proverb Eigenlob stinkt [ee: A man's praise in his own mouth stinks], featured in example (25), expresses criticism, while the proverb Wie man sich bettet, so liegt man [ee: As you make your bed, so you must lie on it], featured in example (26), expresses reproval.

(23) Irren ist menschlich, besagt ein Sprichwort. Das stimmt, jeder macht einmal einen Fehler - das muss zu verzeihen sein. (SprichWort-Plattform)

(24) Mit dem grossen Spielrasen, einem weiträumigen Hofplatz, den Teerflächen, den grosszügigen Veloständern und dem geplanten Kinderspielplatz ... wird auch das Umfeld der Mehrzweckhalle für Schule und Dorfbevölkerung zu einer Attraktion werden. Das Werk lobt den Meister. Die Schulgemeinde tritt als Bauherr auf. (SprichWort-Plattform)

(25) Die Kanzlerin klopfte sich zufrieden auf die Schulter: Deutschland sei bei der Eindämmung der Finanzkrise unter Europas führenden Nationen. Das Eigenlob stinkt gleich mehrfach. Zum einen investiert etwa Frankreich gleich sechs Mal mehr Geld pro Jahr zur Ankurbelung der Wirtschaft: 26 statt zaghafter sechs Milliarden Euro. Zum anderen verdient das Maßnahmenpaket, das die Kanzlerin durch den Bundestag brachte, kaum den Namen Konjunkturprogramm. (SprichWort-Plattform)

(26) Wie man sich bettet, so liegt man bekanntlich. Von daher verwundert es schon, mit welch ungeeignetem Werkzeug manche Heimwerker sich ans Basteln, Schrauben und Renovieren machen. (SprichWort-Plattform)

However, it is difficult to clearly identify and distinguish between the various functions of proverbs in non-argumentative communicative contexts. Due to the dominant interpretative methodological approach towards observing the functions of proverb usage $^{76}$, it is often possible to detect combinations of functions, among which one or more functions can be prevalent. ${ }^{77}$ In this regard, the proverb Aller Anfang ist schwer [ee: Every beginning is difficult], featured in example (27), may express either an apology, praise and/or consolation (expressive speech acts), while it can also be perceived as argumentative justification at the same time.

(27) Es ist eine knifflige Arbeit, die Sorgfalt und eine leichte Hand erfordert. Eine Menge Leisten landen im Müll. „Das macht gar nichts, aller Anfang ist schwer“, tröstet Linke, der das Bemühen der Jungen honoriert. (SprichWort-Plattform)

76 Lüger (1999: VII): "Describing the aspects of function requires the application of interpretative methods."

77 In this regard, Kindt (2002: 284) refers to vast complexes of action, which facilitate the argumentative and non-argumentative communicative functions of proverbs. 
Therefore, it is valid to pose the question if certain types or groups of proverbs may particularly be suitable for carrying out individual speech acts, and if particular proverbs may be preferred as means for performing individual speech acts, (as has been ascertained with regard to the verbalization of topoi above). To my knowledge, something similar has not been concluded yet, so that further research on the topic of speech-act-related functions of proverbs remains still an important desideratum for paremiological pragmatics.

\subsubsection{Proverbs in Text-constituting and Text-structuring Functions}

Proverbs are considerably used as means of organising and structuring the text (Burger, 1987; Lüger, 1999: 190; Rothkegel, 2000; Sandig, 1996; 2007: 168); Ptashnyk, 2009: 180). What is meant here is the facilitation of coherence and cohesion, in other words, the construction of thematically structured texts, that can be interpreted as cohesion-and-coherence-providing functions or text-forming potential respectively (Dobrovol'skij, 1980; Sabban, 2007). ${ }^{78}$ The functional potential of proverbs regarding text-organizing and text-structuring is generally substantiated in their structural and semantic separability and particularly in their relation to individual texts types (Sabban, 2007: 239).

The contribution of proverbs to text-organizing is often related to the manner in which they are positioned in a text. Even though proverbs can essentially appear in any textual position, the usage of proverbs is functional-pragmatically heterogeneous and stylistically conspicuous (also due to their distinctive modifiability) when they are featured in prominent parts of a text; such as the beginning or the end of a text, the beginning or the end of a text segment, the title, the subtitle, or even in the text (segment) frame. This particularly applies to opinion-based journalistic texts. Therefore, the following examples of proverb usage have been chosen from this particular type of text. The following will be observed in this regard:

a) The proverb located at the beginning of a text (segment) (anteposition according to Čermák, 1998);

The proverb determines the topic of a respective text and institutes the general situational frame - the function of introducing the topic (Lüger, 1999: 193; Ptashnyk, 2009: 183) or constituting it globally (Sandig, 2007: 168).

78 The term text-forming potential emanates from Soviet phraseological research (Černyševa) and its function-oriented observation of phraseology in textual contexts. 
(28) Scherben bringen Glück [ee: Shards bring happiness]- das gilt auch in der Ukraine. Bei ihrer ersten Probe für den Eurovision Song Contest hatte die ukrainische Sängerin Ruslana mit ihrem »Wild Dance" letzte Woche die gläserne Bühne [...] in Istanbul zertrümmert; im Finale am Samstagabend siegte sie auf der hastig erneuerten Glasfläche souverän. (SprichWort-Plattform)

Proverbs are often prominently featured in the titles or the subtitles ${ }^{79}$ of mass media texts. Proverbs featured in headlines enable short, concise and opinion-based (expressive) introductions of the topic and thus perform an attention-directing pragmaticstylistic function, acting as "retainers" (Rothkegel, 2000: 240). They are supposed to establish contact with the reader, facilitate and possibly evoke their attention, and provide an incentive for reading (all in the function to emotionalise), while establishing coherence with the content of the respective text at the same time.

\section{(29) Kommt Zeit, kommt Rat [ee: Time will tell]}

Europa scheitert nicht an einer 58-tägigen Urteilsfindung. Karlsruhe ist gut beraten, sich für die Urteile die notwendige Zeit zu nehmen.

(http://www.theeuropean.de)

The attention-directing effects of proverbs, which are located at the anteposition, often emanate from occasional modifications that are adapted to the content of a text, as they are perceived as marked stylistic deviations from the anticipated norm in particular situation-related communicative contexts. In example (30), the lexical expansion, along with the semantic alteration (the addition of the lexeme nicht [not]) of the usual proverb Ende gut, alles gut [ee: All's well that ends well] to Ende gut, nicht alles gut [All's not well that ends well], classifies both the central topic of the text (difficulties that have become apparent after the end of the festival) and its expressive value

(30) Berlinale in der Krise

Ende gut, nicht alles gut

Die Berlinale steckt in einer schweren Krise im Wettbewerb der großen Festivals. (http://www.tagesspiegel.de, 16. 2. 2013)

The prominent featuring of proverbs in titles or at the beginning of a text is often indicated trough additional typographical marking in the form of altered typography or through the addition of quotation marks, indicating the speaker's/writer's intention to influence the recipient's/reader's attention;

79 However, in this regard Čermák (1998) speaks about non-prototypical usage of proverbs. 
(31) »Unkraut vergeht nicht « [ee: Bad weeds grow tall]

Formel-1-Weltmeister Michael Schumacher hat sich beim ersten öffentlichen Auftritt nach dem Horror-Crash in Monza gut erholt gezeigt und freut sich auf den Großen Preis von Italien. (SprichWort-Plattform)

(32) »Einmal ist keinmal« [ee: Once does not count]- das mögen viele denken, die zum ersten Mal zu illegalen Drogen wie Cannabis greifen. Aber wie gefährlich solche Substanzen sind, unterschätzen gerade Jugendliche, die erstmals mit Cannabis in Berührung kommen. (SprichWort-Plattform)

When particular media and specific contexts are considered (newspaper articles, advertising, comics, cartoons, online media communication), the usage of proverbs for the purpose of gaining attention is often supported by non-verbal means (images, artwork). Such means are applied to illustrate particular contexts or, in other words, to visualize the literal meaning of proverbs, which can enhance the pragmatic effects of proverb usage. ${ }^{80}$

In example (33), the proverb Der Krug geht so lange zum Brunnen, bis er bricht [ee: The pitcher will to the well once too often], located in the anteposition, is understood as expressive emphasis of the central statement of the text (the city wells are degenerating). The generalizing content of the proverb (questionable action lead to failure) is projected to a concrete situation and introduces what is to follow in the text (description of unreasonable actions that facilitated the decaying of the wells). The explicit repetition of an element of the proverb (Brunnen, City-Brunnen [wells, city wells]) and of assorted components of the proverb's content (verkommen, defekt, trocken [degenerate, out of order, dry]) in the proceeding text leads to semantic correlation on the surface of text, facilitates a literal reading approach, establishes cohesion and coherence:

(33) Brunnen in der Stadt verkommen

Stuttgart - Der Krug geht so lange zum Brunnen, bis er bricht.

Dieses Sprichwort gilt vor allem für die Sparpolitik bei den 250 städtischen Brunnen in Stuttgart. Für jedes Wasserspiel darf das Tiefbauamt dieses Jahr nur noch 4515 Euro ausgeben. 2010 waren es noch 7792 Euro - 3277 Euro mehr!

Resultat: Obwohl die Stadt kurz nach Ostern alle City-Brunnen anstellen wollte, sind jetzt - vier Wochen später - viele von ihnen noch defekt und trocken. Und in den Becken sammelt sich Dreck, Unrat, Müll!

(http://www.bild.de, 28.4. 2013)

80 Interesting examples concerning the relation between texts and images are presented by Lüger (1999: 167; 170). 
In this regard, Ptashnyk (2009: 187) refers to the function of thematic progression; the progression of the topic of a respective text, and in this coherence-inducing frame rightfully includes the expressive, argumentative, emphasizing, and accentuating stylistic-pragmatic functions of (modified) phraseological expressions (including proverbs). Lüger (1999: 190) refers to this process as sequence control and emphasizes its text-structuring function: "Sentence-like phraseological units /are/ preferably used for the purposes of structuring [...]: for initiating a sequence or the entire text, as well as for the purpose of summarizing or concluding extended segments of text respectively“ (Lüger 1999: 193).

b) The proverb located at the end of a text (segment) (postposition according to Čermák, 1998);

The most important function of a proverb, which is located at the end of a text or text segment respectively, is to summarize what has been stated before (generalizing and/ or commenting pointed emphasis).

(34) Bislang zahlen die Jüngeren, soweit sie arbeiten, für die Rentner. Im Bonner Frühling wird davon geträumt, jeden seine Rente selbst ansparen zu lassen, was ein großer Schritt von der Solidarität zur Individualisierung wäre. Jeder ist seines Glückes Schmied [ee: Every man is the architect of his own fortune]. (SprichWort-Plattform)

(35) Unter einem Polterabend versteht man den Brauch, einem Brautpaar vor dessen Heirat durch das Zerbrechen von Porzellan ein Gelingen der Ehe zu wünschen, nach dem Sprichwort: „Scherben bringen Glück» [ee: Shards bring happiness]. (SprichWort-Plattform)

It is not only the specific, stylistically conspicuous conclusion of a text sequence understood here, through the figurative character of a proverb emerges a certain expressivity of expression, and with it also the "aesthetic or persuasive topping of a text”(Sandig, 1996: 290). The usage of phraseological expressions (including proverbs) in such manner is often text-type-specific. Phraseological units often represent the focal "point" - the punchline of a joke or an anecdote (Wotjak, 1994 \& 1999).

c) Proverbs in the function of a text (sequence) framing elements

Proverbs are particularly used in opinion-based journalistic text types (articles, squibs etc.) for the purpose of establishing the structural frame of a respective text;

(36) „Wir sitzen alle in einem Boot“ [ee: We are all in the same boat] ist eine Charakterisierung von Solidarität in der Erklärung der beiden großen Kirchen zur sozialen und 
wirschaftlichen Lage. Sie haben Recht. Wir sitzen in einem Boot. Aber einige müssen rudern. (Die Zeit, 28. 3. 1997; example quoted from Ptashnyk, 2009: 203).

The pragmatic text-organizing or text-structuring function is based on the repetitive occurring of a proverb in a contextual frame, in which the main statement (the text or a text segment) can be interpreted as expressive and argumentative.

To summarize: Proverbs are often featured in prominent parts of texts relevant to text structure: in the headline, at the beginning and at the end of a text. This way they function as text-constituting and text-structuring elements. The prominent featuring of proverbs in a text hints at conspicuous usage and facilitates additional stylistic and pragmatic effects such as influencing the attention of the recipient/reader, an increase in the degree of expressivity, emotions etc. Proverbs evidently contain features, which enable specific usage of text. Therefore, it would be of advantage to systematically observe and to determine the relations between proverbs and texts from the perspective of text linguistics. The correlation between types of phraseological expressions and text types or, in other words, between the features and functions of proverbs and text types, would be of particular interest in this regard. In concrete terms, the question hinted by Sabban (2007: 238) could thus be posed as follows: How can proverbs be used based on their distinct properties to contribute to the various dimensions of texts in an extraordinary, if not crucial manner?

\subsection{Conclusion and Outlook}

The observation of the stylistic and pragmatic aspects of proverbs within the scope of this paper was conducted from the perspective of traditional stylistics and from the perspective of the modern pragmatic and text linguistic concept of style. We have seen that the traditional narrow understanding of style considers proverbs as stylistic devices and assigns them characteristic stylistic labels aside of the textual usage. If we however understand style as a functional-pragmatic textual dimension, it is essential to observe proverbs in complex textual-situational contexts.

This concise presentation of stylistics and pragmatics of proverbs is not thorough or absolute in terms of interpretation Particularly on the grounds of the extraordinary diversity of proverbs, the present paper is intended as an initial orientation and aspires to be considered as an impulse for further research in this area. A requirement for further studies is evident in many respects. With regard to the frequently criticized lexicographic practice, it would be necessary to determine the criteria and principles for the classification of labels for denoting register and the type of style coloring. It would be interesting to observe if particular types or groups of proverbs are particularly suitable for realizing individual speech acts, and if particular proverbs may be preferred as means for realizing speech acts to a larger degree than others. 
Additionally, it would also be of advantage to ascertain if all proverbs appear in argumentative contexts in equal measure, and if certain proverbs are preferred in specific situation-and-text-type-based contexts with regard to their respective degree of argumentative force. What is generally missing as well are theoretical methods for assigning functions to proverbs in textual and discursive contexts based on the usage of proverbs in concrete, context-related statements (see Kindt, 2002: 277). From an interlingual perspective, it would be necessary to establish so-called functional interlinguistic paremiological equivalence in order to consider stylistic-pragmatic parameters of comparison to a greater extent when determining equivalence relations. Proverbs contain significant stylistic-pragmatic potential, which is why there is a demand for a holistic pragmalinguistic approach towards studying the usage of proverbs. In conclusion, it is to be emphasized that detailed studies of the stylistic-pragmatic potential and functions of proverbs require interdisciplinary research, which consider the stylistic-pragmatic perspective, the perspective of text linguistics, the perspective of corpus linguistics, as well as the perspective of contrastive phraseology/paremiology.

\section{References}

Bally, C. (1909). Traitè de stylistique française. Volume I. Paris: Klincksieck.

Burger, H. (1987). Funktionen von Phraseologismen in den Massenmedien. In H. Burger \& R. Zett (eds.), Aktuelle Probleme der Phraseologie (pp. 11-28). Bern: Peter Lang.

Burger, H. (2010). Phraseologie. Eine Einführung am Beispiel des Deutschen. 4., neu bearb. Aufl. Berlin: Erich Schmidt Verlag.

Bußmann, H. (ed.) (2002). Lexikon der Sprachwissenschaft. 3., aktualisierte und erw. Aufl. Stuttgart: Alfred Kröner Verlag.

Columas, F. (1981). Routine im Gespräch. Zur pragmatischen Fundierung der Idiomatik. Wiesbaden: Akademische Verlagsgesellschaft Athenaion.

Čermák, F. (1998). Usage of Proverbs. What the Czech National Corpus Shows. In P. Ďurčo. (ed.), Europhras 97: Phraseology and Paremiology. International Symposium, September 2-5, 1997, Liptovský Ján (pp. 37-45). Bratislava: Akademia PZ.

Dietz, H.-U. (1999). Rhetorik in der Phraseologie. Zur Bedeutung rhetorischer Stilelemente im idiomatischen Wortschatz des Deutschen. Tübingen: Niemeyer.

Dobrovol'skij, D. (1980). Zur Dialektik des Begriffs der textbildenden Potenzen von Phraseologismen. Zeitschrift für Phonetik, Sprachwissenschaft und Kommunikationsforschung 33, 690-700.

Drescher, M. (1997). Wie expressiv sind Phraseologismen? In A. Sabban (ed.), Phraseme im Text. Beiträge aus romanistischer Sicht (pp. 67-95). Bochum: Brockmeyer.

Duden Deutsches Universalwörterbuch (2006). Berlin: Bibliographisches Institut \& FA Brockhaus.

Duden online. Berlin: Bibliographisches Institut. http://www.duden.de/woerterbuch (accessed November 29, 2013).

Duden Redewendungen (2013). Wörterbuch der deutschen Idiomatik. 4., neu bearb. und aktual. Aufl. Berlin/Mannheim/Zürich: Dudenverlag.

Eikelmann, M. (2002). Zur historischen Pragmatik des Sprichworts im Mittelalter. In D. Hartmann, \& J. Wirrer (eds.), Wer A sägt, muss auch B sägen. Beiträge zur Phraseologie und Sprich- 
wortforschung aus dem Westfälischen Arbeitskreis (pp. 95-105). Baltmannsweiler: Verlag Hohengehren.

Elspaß, S. (1998). Phraseologie in der politischen Rede. Zur Verwendung von Phraseologismen in ausgewählten Bundestagsdebatten. Opladen, Wiesbaden: Westdeutscher Verlag.

Filatkina, N. (2007). Pragmatische Beschreibungsansätze. In H. Burger et al. (eds.), Phraseologie. Ein internationales Handbuch der zeitgenössischen Forschung. 1. Halbband (pp. 132-158). Berlin/New York: de Gruyter.

Fleischer, W., Michel, G. \& Starke, G. (1993). Stilistik der deutschen Gegenwartssprache. Frankfurt am Main: Peter Lang.

Grzybek, P. (1984). Überlegungen zur semiotischen Sprichwortforschung. P. Grzybek (ed.), Semiotische Studien zum Sprichwort. Simple Forms Reconsidered I. Special Issue of Kodikas Code - Ars Semiotica. An International Journal of Semiotics 3/4, 215-249

Harnisch, R. M. (1995). Proverbs and Pragmatics I: Prolegomena to a Comparison of English and Hungarian. In K.Sornig et al. (eds.), Linguistics with a Human Face: Festschrift für Norman Denison zum 70. Geburstag (pp. 135-146). Graz: Grazer Linguistische Monographien 10.

Hausmann, F. J. (1989). Die Markierung im allgemeinen einsprachigen Wörterbuch: eine Übersicht. In F. J. Hausmann et al. (eds.), Wörterbücher. HSK. Teilbd. 1 (pp. 649-657). Berlin/New York: de Gruyter.

Hemmi, A. (1994). Es muss wirksam werben, wer nicht will verderben. Kontrastive Analyse von Phraseologismen in Anzeigen-, Radio- und Fernsehwerbung. Bern: Peter Lang.

Hoffmann, S. (2009). Wer A sagt, muss auch B sagen. Sprichwörter in der Argumentation. In A. Raev, M. Wagner-Braun \& M. Schambek (eds.), Kolloquium 2009. Beiträge Bamberger Nachwuchswissenschaftlerinnen (pp. 9-23). Bamberg: University of Bamberg Press.

Hoffmann, S. (2012). Argumentative Strukturen in Sprichwörtern. Frankfurt am Main: Peter Lang.

Hrisztova-Gotthardt, H. (2010). Vom gedruckten Sprichwörterbuch zur interaktiven Sprichwortdatenbank. Überlegungen zum linguistischen und lexikographischen Konzept mehrsprachiger Sprichwortdatenbanken. Bern: Peter Lang.

Janz, B. (1992). Dan nach sprichwortten pflegen die bauren gerne zu sprechen. Überlegungen zur Rolle von Rechtssprichwörtern im spätmittelalterlichen Gerichtsverfahren. Proverbium 9 , 81-106.

Kindt, W. (2002). Kommunikative Funktionen von Sprichwörtern: Ein Beispiel für die notwendige Verbindung von Phraseologie und Pragmatik. In E. Piirainen \& I. T. Piirainen (eds.), Phraseologie in Raum und Zeit. Akten der 10. Tagung des Westfälischen Arbeitskreises „Phraseologie/Parömiologie (Münster 2001) (pp. 273-286). Baltmannsweiler: Verlag Hohengehren.

Koller, W. (1977). Redensarten. Linguistische Aspekte, Vorkommensanalysen, Sprachspiel. Tübingen: de Gruyter.

Kühn, P. (1987). Phraseologismen: Sprachhandlungstheoretische Einordnung und Beschreibung. In H. Burger \& R. Zett (eds.), Aktuelle Probleme der Phraseologie. Symposium 27. -29. 9. 1984 in Zürich (pp. 121-137). Bern: Peter Lang.

Kühn, P. (1994). Pragmatische Phraseologie: Konsequenzen für Phraseographie und Phraseodidaktik. In B. Sandig (ed.), Europhras 92. Tendenzen der Phraseologieforschung (pp. 411-428). Bochum: Brockmeyer.

Lewandowska, A. (2008). Sprichwort-Gebrauch heute. Ein interkulturell-kontrastiver Vergleich von Sprichwörtern anhand polnischer und deutscher Printmedien. Bern: Peter Lang.

Linke, A., Nussbaumer, M., \& Portmann, P. R. (1996). Studienbuch Linguistik. 3. Aufl. Tübingen: Niemeyer.

Lüger, H.-H. (1989). Stereotypie und Konversationsstil. Zu einigen Funktionen satzwertiger Phraseologismen im literarischen Dialog. Deutsche Sprache 17, 2-25. 
Lüger, H.-H. (1999). Satzwertige Phraseologismen. Eine pragmalinguistische Untersuchung. Wien: Praesens Verlag.

Nahberger, G. (2002). Ende gut, alles gut - Anmerkungen zu einer sprechakttheoretischen Analyse von Sprichwörtern. In D. Hartmann \& J. Wirrer (eds.), Wer A sägt, muss auch B sägen. Beiträge zur Phraseologie und Sprichwortforschung aus dem Westfälischen Arbeitskreis (pp. 255-272). Baltmannsweiler: Verlag Hohengehren.

Nahberger, G. (2004). Eine Schwalbe macht noch keinen Sommer - eine empirische Untersuchung zur Bedeutungsgenerierung und illokutionären Schlagkraft von Sprichwörtern. In C. Földes \& J. Wirrer (eds.), Phraseologismen als Gegenstand sprach- und kulturwissenschaftlicher Forschung. Akten der europäischen Gesellschaft für Phraseologie (Europhras) und des Westfälischen Arbeitskreises „Phraseologie/Parömiologie“ (Loccum 2002) (pp. 309-324). Baltmannsweiler: Verlag Hohengehren.

Nöcker, R. \& Rüther, H. (2002). Es ist besser in Ehre zu sterben, als mit Schande zu leben. Zur Verwendung situationsmodellierender Phraseologismen in mittelhochdeutschen Romanen des 12. und 13. Jahrhunderts. In E. Piirainen \& I. T. Piirainen (eds.), Phraseologie in Raum und Zeit. Akten der 10. Tagung des Westfälischen Arbeitskreises „Phraseologie/Parömiologie (Münster 2001) (pp. 101-112). Baltmannsweiler: Verlag Hohengehren.

Ottmers, C. (1996). Rhetorik. Stuttgart: Metzler Verlag.

OWID Sprichwörterbuch. www.sprichwort-plattform.org (accessed December 21, 2013).

Preußer, U. (2004). Phraseologismen in literarischen Texten - Zwischen Linguistik und Literaturwissenschaft. In C. Földes \& J. Wirrer (eds.), Phraseologismen als Gegenstand sprach- und kulturwissenschaftlicher Forschung. Akten der europäischen Gesellschaft für Phraseologie (Europhras) und des Westfälischen Arbeitskreises „Phraseologie/Parömiologie“(Loccum 2002) (pp. 267-284). Hohengehren: Schneider.

Ptashnyk, S. (2009). Phraseologische Modifikationen und ihre Funktionen im Text. Eine Studie am Beispiel der deutschsprachigen Presse. Hohengehren: Schneider Verlag.

Racette, D. (1997). Wie das Färberpferd umd die Rolle: Sprichwörtliches in G.E. Lessings Komödien. Proverbium 14, 303-346.

Röhrich, L., \& Mieder, W. (1977). Sprichwort. Stuttgart: Metzler.

Rothkegel, A. (2000). Phraseme: Fenster zur Textkohärenz. In G. Gréciano (ed.), Micro- et macrolexèmes et leur figement discursif: études de linguistique comparée fiançais/ allemand (pp. 233-246). Louvain: Editions Peeters.

Sabban, A. (2007). Textbildende Potenzen von Phrasemen. In H. Burger et al. (eds.), Phraseologie. Ein internationales Handbuch der zeitgenössischen Forschung. 1. Halbband (pp. 237-253). Berlin/New York: de Gruyter.

Sandig, B. (1986). Stilistik der deutschen Sprache. Berlin/New York: de Gruyter.

Sandig, B. (2006). Textstilistik des Deutschen. 2., völlig neu bearb. u. erw. Aufl. Berlin/New York: de Gruyter.

Sandig, B. (2007). Stilistische Funktionen von Phrasemen. In H. Burger et al. (eds.), Phraseologie. Ein internationales Handbuch der zeitgenössischen Forschung. 1. Halbband (pp. 158-175). Berlin/New York: de Gruyter.

Schmale, G. (2010). Ist ein idiomatischer Ausdruck immer expressiv? Korpusbasierte und fragebogengestützte Beobachtungen zu einer verbreiteten Prämisse. Yearbook of Phraseology 1, 97-124.

Searle, J. R. (1983). Sprechakte. Ein sprachphilosophischer Essay. Frankfurt am Main: Suhrkamp. Sowinski, B. (1991). Stilistik. Stiltheorien und Stilanalysen. Stuttgart: Metzler.

Sprichwort-Plattform. http://www.sprichwort-plattform.org/ (accessed November 30, 2013). Umurova, G. (2005). Was der Volksmund in einem Sprichwort verpackt ...: moderne Aspekte des Sprichwortgebrauchs anhand von Beispielen aus dem Internet. Bern: Peter Lang. 
Wirrer, J. (1999). Phraseologie und Rhetorik. In R. S. Baur, C. Chlosta \& E. Piirainen (eds.), Wörter in Bildern, Bilder in Wörtern. Beiträge zur Phraseologie und Sprichwortforschung aus dem Westfällischen Arbeitskreis (pp. 421-455). Hohengehren: Schneider.

Wirrer, J. (2007). Phraseme in der Argumentation. In H. Burger et al. (eds.), Phraseologie. Ein internationales Handbuch der zeitgenössischen Forschung. 1. Halbband (pp. 175-187). Berlin/ New York: de Gruyter.

Wotjak, B. (1994). Fuchs, die hast du ganz gestohlen. Zu auffälligen Vernetzungen von Phraseologismen in der Textsorte Anekdote. In B. Sandig (ed.), EUROPHRAS 92. Tendenzen der Phraseologieforschung (pp. 619-650). Bochum: Brochmeyer.

Wotjak, B. (1999). Zu textuellen Vernetzungen von Phraseologismen am Beispiel von Sprachwitzen. In: N. Fernandez-Bravo, I. Behr, \& C. Rozier (eds.), Phraseme und typisierte Rede (pp. 51-62). Tübingen: Stauffenburg. 